\title{
Pigs' Husbandry as Case Study to Test Effects of Vegetable Residues' Hydrolysates on Animals
}

\author{
M. Morlacchini ${ }^{1}$, G. Fusconi ${ }^{1}$, C. Montoneri $^{2}$, R. Nisticò ${ }^{3}$, E. Montoneri ${ }^{4 *}$ \\ ${ }^{I}$ CERZOO - Centro Ricerche per la Zootecnia e l'Ambiente, Via Castellarino, 12, Località S. Bonico, 29122 \\ Piacenza-(PC), Italy \\ ${ }^{2}$ Mayes \& Scrine, Dawes Farm, Bognor Road, Warnham, Horsham, West Sussex RH12 3SH, UK \\ ${ }^{3}$ Polytechnic of Torino, Department of Applied Science and Technology, DISAT, Corso Duca degli Abruzzi 24, \\ 10129 Torino (TO), Italy \\ ${ }^{4}$ Università di Torino, Dipartimento di Scienze Agrarie, Forestali e Alimentari, Largo P. Braccini 2, 10095 \\ Grugliasco (TO), Italy
}

\begin{abstract}
*Corresponding Author: E. Montoneri, Università di Torino, Dipartimento di Scienze Agrarie, Forestali e Alimentari, Largo P. Braccini 2, 10095 Grugliasco (TO), Italy, Email: enzo.montoneri@ gmail.com
\end{abstract}

\begin{abstract}
Soluble biopolymers ( $S B O$ ) are research products obtained from alkaline hydrolysis of municipal and agriculture bio-residues. They contain a mix of soluble macromolecules with different $C$ types and functional groups. These features make SBO multipurpose products for the chemical industry, agriculture and animal husbandry. As such, they may contribute to the development of bio-based circular economy by recycling renewable carbon over urban and agriculture environments. To foster production and commercialization, assessment of SBO's compliance with countries' regulations is mandatory. The authors performed the present in vivo pigs study to investigate quality, safety, and efficacy of SBO's as animal feed supplement. Total 106 male and female piglets were fed 42 days with protein-based diets containing 0.1 and $0.2 \%$ SBO. Pigs grew from average 7.7 to $26 \mathrm{~kg}$. Average mortality rate was $3.9 \%$. Relatively to control diets with no added SBO, the diets containing 0.1 and $0.2 \%$ SBO evidenced no significant effects on pigs' growth, mortality, and anatomy and pathology of dead animals. A previous rabbit study reported similar results for SBO supplemented diets. The authors discuss the economic and environmental implications of the results in relation to $S B O$ potential marketability.
\end{abstract}

Keywords: Bio wastes; bio macro molecules; pigs; rabbits; animal husbandry; regulatory requirements.

Abbreviations: Af, aliphatic carbon; CP, compost; COX, carboxyl carbon; HS, humic substances; IR, insoluble residue; $M B W$, municipal biowaste; NR, amine carbon; OCO, anomeric carbon; OME, methoxy carbon; Ph, aromatic carbon; PhOY, phenoxy carbon; $S B O$, soluble biopolymers

\section{INTRODUCTION}

Soluble biopolymers (SBO) obtained from alkaline hydrolysis of bio-residues from municipal and agriculture source are multipurpose products for use in diversified fields (Montoneri, 2017). Examples are the fabrication and/or formulation of detergents, dyeing baths, flocculants, dispersants, binding agents for ceramics manufacture, emulsifiers, auxiliaries for soil/water remediation and enhanced oil recovery, nanostructured materials for chemical and biochemical catalysis, plastic materials, soil fertilizers and plant biostimulants for agriculture. The SBO are composed by a heterogeneous pool of macromolecules with 67-
$463 \mathrm{~kg} \cdot \mathrm{mol}^{-1}$ molecular weight and 6-53 polydispersity index. They contain aliphatic and aromatic $\mathrm{C}$ chains substituted by a wide variety of acid and basic functional groups of different strength (Tabasso et al., 2015). Their chemical nature bears chemical similarities with natural humic substances (HS).

The above findings prospect implementation of a bio-waste based circular economy, based on the following hypothetical scenario. The hydrolysis of municipal food wastes, private gardens and public parks trimmings, and postharvest plant residues yields SBO for use in agriculture and for the manufacture of consumers' chemical product in everyday life. 
Renewable $\mathrm{C}$ is recycled repeatedly over the agriculture and urban environment. Biowaste treatment plants (Montoneri et al., 2011) become biorefineries, producing bio-based fuel and chemicals. SBO replace products from fossil sources. This reduces the depletion of fossil sources and the environmental impact of not renewable fuel and chemicals. The economy of biowaste treatment plants improves. The biowaste based economy produces socio-economic benefits; such has reduction of citizens' taxation for waste management and creation of new jobs (Montoneri, 2017).

The SBO are not commercial products yet. To contribute to the realization of the above perspectives, a hydrolysis prototype plant is under construction within the municipal biowaste (MBW) treatment plant of Acea Pinerolese in Pinerolo (TO), Italy. Acea collects MBW from 150,000 inhabitants of 47 municipalities (Montoneri et al. 2011). It process MBW through integrated anaerobic and aerobic fermentation. It produces biogas and compost, and thermal and electrical power from biogas for the nearby residential district. The prototype plant will be integrated into the existing biochemical facilities to hydrolyze the plant anaerobic fermentation digestate and/or the compost, produce 400-800 t/y SBO and validate the SBO performance and marketability in real operational conditions. In this scenario, it is essential assessing the compliance of SBO with countries' regulatory requirements to ensure the quality, safety, and efficacy of the product and obtain its marketing authorization (Handoo et al., 2012).

Marketing approval of new products is quite complex process. It involves the assessment of critical parameters during product development. The regulatory requirements of various countries of the world vary from each other. Therefore, it is quite challenging to collect data, which is suitable to obtain approval in different countries. In the case of SBO, the authors have considered the Italian legislation on fertilizers, as starting point. The most recent Italian legislation on fertilizers (Presidente della Repubblica, 2010; Ministero delle Politiche Agricole e Forestali, 2017) allows marketing HS or HS-like products obtained by extraction of soil, peat or other fossil materials, or mixtures of vegetable materials after anaerobic and/or aerobic fermentation. Based on chemical composition, sourcing material and production process (see section 2.1), the SBO fall well into the above category of fertilizers.
The chemical similarity (Montoneri, 2017) of SBO with HS is a favorable feature, in relation to the perspective of successfully demonstrating the safety of SBO for commercial use. Humic substances isolated from soil or fossils are efficient for use as diet supplement in animal husbandry (Montoneri et al., 2013; Biagini et al., 2016). Use of SBO, in place of HS, appears highly desirable for reasons linked to the greater availability of biowastes and to the need to reduce landfill areas for biowaste disposal. Agriculture and animal husbandry constitute important markets for the potential allocation of large amounts of SBO. These facts offer worthwhile scope for investigating the full potential feasibility of SBO to enter the market.

Sortino et al. (2012), Montoneri et al. (2013) and Biagini et al. (2016) have dedicated studies to assessing the performance and safe use of SBO. Sortino et al. (2012) carried out an on field tomato cultivation study, adding SBO to the cultivation soil. They found that, compared to the no treatment and to the treatment using commercial fertilizers, the SBO enhance significantly plant growth and crop production, while not affecting chemical composition of soil and leaves. The authors concluded that the potential adverse environmental impact of periodically repeated applications of SBO to the same soil should raise no more concern than that contributed by conventional mineral and organic fertilizers.

Montoneri et al. (2013) performed an in vitro fermentation study to test SBO as diet supplements to modulate pig's cecal fermentation of a protein feed. They added SBO at $0.05-0.2 \%$ level in the fermentation slurry. The results showed that, during fermentation, ammonia production in the fermentation slurry containing SBO decreased by $17 \%$, compared to the control fermentation with no added SBO. The authors ascribed the SBO effect to reduced proteolysis and $\mathrm{N}$ mineralization. They expected favourable economics and lower environmental impact for the animal production industry, stemming from the use SBO as animal feed supplements.

Biagini et al. (2016) carried out an in vivo animal study. They evaluated the effect of different doses of SBO as feed additives in diets for fattening rabbits. Rabbits are herbivorous non-ruminants. They are able to utilize a wide range of feed resources. The rich microbial intestinal population (particularly at the caecum level) influences the post-gastric digestion of 
such animals. One of the leading causes of mortality is disease of the digestive apparatus, involving the microbiota. This feature makes the use of rabbits interesting to assess the influence of SBO on animal welfare and intestinal microflora. Rabbits serve to bridge the gap between the small animal models, which are perhaps more suitable for biomedical research, and larger animals used for animal production. The results of Biagini et al. (2016) study showed that diets containing $0.05-1 \% \mathrm{w} / \mathrm{w}$ do not affect the live and slaughtering performances, except for the intestinal tract absorption area (higher in the intestines of rabbits fed with the high SBO content) or the apparent digestibility of the feed (lower in diets with low or no SBO content). The authors concluded that SBO might perform as feed additive for rabbits, without any adverse effects on animal productivity and health.

To find whether the encouraging results on the safe use of SBO in rabbits' diet were general for other animals, the present work reports the in vivo study on pigs husbandry performed with diets containing similar SBO amounts as in the rabbits study. Pigs are large animals. Pigs and

Table1. Analytical data for pristine compost (CP), SBO and IR

\begin{tabular}{|c|c|c|c|c|c|c|c|c|c|c|c|c|c|}
\hline & \multicolumn{2}{|l|}{$\mathrm{pH}$} & \multicolumn{3}{|c|}{ Volatile Solids, w/w \% ${ }^{\mathrm{a}}$} & \multicolumn{3}{|c|}{$\mathrm{C}, \mathrm{w} / \mathrm{w} \%^{\mathrm{a}}$} & \multicolumn{3}{|c|}{$\mathrm{N}, \mathrm{w} / \mathrm{w} \%^{\mathrm{a}}$} & \multicolumn{2}{|c|}{$\mathrm{C} / \mathrm{N}$} \\
\hline $\mathrm{CP}$ & \multicolumn{2}{|c|}{7.3} & \multicolumn{3}{|c|}{42.9} & \multicolumn{3}{|c|}{$22.4 \pm 0.4$} & \multicolumn{3}{|c|}{$1.91 \pm 0.03$} & \multicolumn{2}{|c|}{11.7} \\
\hline SBO & \multicolumn{2}{|c|}{8.2} & \multirow{2}{*}{\multicolumn{3}{|c|}{$\frac{7.1}{28.7}$}} & \multicolumn{3}{|c|}{$38.2 \pm 0.1$} & \multicolumn{3}{|c|}{$4.01 \pm 0.03$} & \multicolumn{2}{|c|}{9.54} \\
\hline \multirow[t]{3}{*}{ IR } & 8.7 & & & & & & $18.4 \pm 0.7$ & & & \pm 0.09 & & & 5.0 \\
\hline & \multicolumn{13}{|c|}{ Mineral elements: $\mathrm{Si}, \mathrm{Fe}, \mathrm{Al}, \mathrm{Mg}, \mathrm{Ca}, \mathrm{K}, \mathrm{Na}$ as $\% \mathrm{w} / \mathrm{w} ;{ }^{\mathrm{a}} \mathrm{Cu}, \mathrm{Ni}, \mathrm{Zn}, \mathrm{Cr}, \mathrm{Pb}, \mathrm{Hg}$ as ppm ${ }^{\mathrm{a}}$} \\
\hline & $\mathrm{Si}$ & $\mathrm{Fe}$ & $\mathrm{Al}$ & $\mathrm{Mg}$ & $\mathrm{Ca}$ & $\mathrm{K}$ & $\mathrm{Na}$ & $\mathrm{Cu}$ & $\mathrm{Ni}$ & $\mathrm{Zn}$ & $\mathrm{Cr}$ & $\mathrm{Pb}$ & $\mathrm{Hg}$ \\
\hline $\mathrm{CP}$ & 12.1 & 1.03 & 0.59 & 1.67 & 4.86 & 1.18 & 0.06 & 73 & 100 & 157 & 49 & 43 & 0.31 \\
\hline SBO & 2.55 & 0.77 & 0.49 & 1.13 & 6.07 & 3.59 & 0.16 & 202 & 92 & 256 & 19 & 85 & 0.15 \\
\hline \multirow[t]{3}{*}{ IR } & 15.0 & 1.10 & 0.67 & 1.45 & 4.19 & 1.49 & 0.06 & 51 & 102 & 123 & 34 & 39 & 0.07 \\
\hline & \multicolumn{13}{|c|}{$\mathrm{C}$ types } \\
\hline & $\mathrm{Af}$ & $\mathrm{OMH}$ & $+\mathrm{NR}$ & OR & $\mathrm{OCO}$ & $\mathrm{Ph}$ & $\mathrm{PhOY}$ & & $\mathrm{CO}$ & & $\mathrm{C}=$ & & $\mathrm{Af} / \mathrm{Ar}$ \\
\hline $\mathrm{CP}$ & 32.9 & & 33 & 23.8 & 6.34 & 12.3 & 6.73 & & 8.2 & & 1.3 & & 1.7 \\
\hline SBO & 36.9 & & 24 & 13.2 & 4.18 & 13.4 & 6.84 & & 13. & & 4.6 & & 1.8 \\
\hline IR & 31.7 & & 43 & 24.6 & 6.14 & 11.5 & 7.23 & & 7.7 & & 2.6 & & 1.7 \\
\hline
\end{tabular}

${ }^{a}$ Concentration values referred to dry matter: averages and standard deviation calculated over triplicates.

${ }^{b}$ Aliphatic (Af), aromatic (Ph), methoxy (OMe), carboxyl (COX, X = OH or NR), ammine (NR), alkoxy (RO), phenoxy (PhOY, $Y=O H$ or $R$ ) and anomeric (OCO) C atoms, $R=H$, alkyl or phenyl $C$.

Table2. Proximates' composition (\% $w / w)$ for $S B O$

\begin{tabular}{|l|l|}
\hline $\mathrm{H}_{2} \mathrm{O}$ & 2.34 \\
\hline Crude protein & 18.0 \\
\hline Crude fat & 0.07 \\
\hline ADF & 52.4 \\
\hline ADL & 33.8 \\
\hline P & 0.27 \\
\hline Gross energy, MJ/kg & 13.3 \\
\hline
\end{tabular}

The data in Table 1 were obtained by $13 \mathrm{C}$ NMR spectroscopy, potentiometric titration, elemental $\mathrm{C}$ and $\mathrm{N}$, and mineral elements, humans have anatomical and physiological similarities (Kobayashi et al., 2012). Pigs are models in biomedical research and toxicology testing (Swindle et al., 2012).

\section{MATERIALS AND METHODS}

\subsection{SBO Preparation and Characterization}

The SBO were obtained and characterized, as previously reported (Montoneri, 2017). Urban private gardening residues and public park trimmings collected in the province of Torino, Italy, were composted for 280 days. The compost was hydrolysed $4 \mathrm{~h}$ at $60{ }^{\circ} \mathrm{C}$ in aqueous $\mathrm{KOH}$ at $\mathrm{pH} 13$ and 4 liquid/solid w/w ratio. Centrifugation of the recovered slurry separated the insoluble residue (IR) from the aqueous hydrolysate. Filtration of the recovered liquid phase through a $5 \mathrm{kDa}$ cut off polysulphone membrane yielded the retentate and the permeate. Drying at $60{ }^{\circ} \mathrm{C}$ the retentate yielded the solid SBO in $30 \% \mathrm{w} / \mathrm{w}$ amount, relative to the pristine compost $(\mathrm{CP})$. The compost, and the IR and SBO products, were characterized by the data reported in Table 1 and 2. according to a protocol specifically developed for biowaste derived materials (Tabasso et al., 2015; Montoneri et al., 2013; Sortino et al., 
2012). The data in Table 2 were obtained according to AOAC (2006).

\subsection{Pigs Feeding Trials}

The animal study was performed in 2011, in compliance with the Italian national legislation on the use of animals for research (Presidente della repubblica, 1992). The experimental work was performed according to the commonly accepted '3Rs' EU guidelines at the Cerzoo facilities (Università Cattolica del Sacro Cuore, 2017) in Piacenza, Italy. Before starting the work, the authors submitted the ethics committee of the local Italian authority (A.USL di Piacenza, 2017) the 2011 document (see supplementary material file), which contained all experimental details of the planned work. According to the above regulation, this document accomplished the legal requirements to start the work. The test animals were 54 castrated male and 54 female weaned piglets with average $7.74 \pm 0.46 \mathrm{~kg}$ weight, genetic type commercial hybrids. Agricola Serena di Lingiardi Sandro Fabrizio, Cascina Serena, Via Strada Provinciale, 104 - 24051, Antegnate (BG), Italy, AUSL code 007 LO 011 supplied the animals. These were housed in pens within a sun-lighted building, where temperature and humidity were controlled through water heaters and a computerized automatic ventilation system. The pens were equipped with mangers and automatic water nipple drinkers to dispense potable water analyzed for $\mathrm{Na}, \mathrm{K}, \mathrm{Ca}, \mathrm{Cl}$ and $\mathrm{E}$. coli.

Before starting the trials, pens were disinfected with non-toxic substances. Animals were subjected to veterinary examination health conditions and then placed in the pens, each containing three males or three females. The experimental plan comprised testing each feeding diet (Table 3) over 36 animals, corresponding to twelve replicates for each diet. Each treatment was equivalent for animal weight and sex. The diets did not contain zootechnical additives according to EU Reg.1831/03 (European Commission, 2017). They were iso-nutritive in each feeding period, according to the feed requirements as a function of age and weight (Fanimo et al., 2003). Mangimificio Rossana, Revere (Mantova), Italy prepared the two basal diets for the two different feeding periods. Cerzoo Piacenza, Italy, prepared the treatment diets by adding the required SBO amount to the basal diet and homogenizing through a horizontal mixer. Before the addition of SBO, examination of the basal diets guaranteed no cross contamination. Except for the added SBO, no other products were added to the basal diets. During the feeding periods, the trials were monitored twice a day, in the morning and in the afternoon, by examining the animals' health conditions, and checking the availability of feed and water, and the correct functioning of the temperature and humidity control system. Animal growth was monitored by measuring the animal body weight at day zero, 14 and 42, and the feed consumption at day 14 and 42. Diets' analyses were carried out on $250 \mathrm{~g}$ samples. Diets were analysed according to ISO methods, for the content of water (ISO, 2016a), ashes (ISO, 2013a), starch (ISO, 2013b), crude protein (ISO, 2014), ether extracts (ISO, 2016b), crude fibre (ISO, 2017), digestible (Morgan et al., 1987) and net (Noblet et al., 1994) energy. Values for these analytes, and for NDF, ADF, ADL and amino acids, were also calculated using Brill formulation feed management systems version 2.03, 2011, Brilliant Alternatives Inc., USA.

\subsection{Statistical Analyses}

Data were analysed by Anova using SAS, 20022008, version9.2 software. Averages over replicates were compared by Student t-test. The body weight data were analysed also for outliers. None was evident on day 14 and 42.

\section{RESUlts}

\subsection{Chemical Composition of SBO and sourcing compost}

The SBO used in the pigs' husbandry study is the same as the one used in the pigs in vitro study (Montoneri et al., 2013) and in the rabbits in vivo study (Biagini et al., 2016). They were obtained by hydrolysis in alkaline water of composted urban private gardening residues and public park trimmings collected in the province of Torino, Italy (see Section 2). The process yields SBO and an insoluble residue (IR). Table 1 and 2 report the collected chemical data for the pristine compost (CP) and the SBO and IR hydrolysates. Determination of the chemical structure of these materials is not as easy as for synthetic molecules. As anticipated in section 1 , they contain molecules of different molecular weights and chemical composition. These materials are characterized at best for the content of the analytes reported in Table 1. It is 
not possible to identify a specific molecular structure. Nevertheless, the analytical data give some important information. The three materials contain organic and mineral matter. Compared to $\mathrm{CP}$ and IR, SBO contain more organic matter and less mineral matter, except for $\mathrm{Ca}, \mathrm{K}, \mathrm{Cu}$, $\mathrm{Zn}$ and $\mathrm{Pb}$.

The higher content of $\mathrm{K}, \mathrm{Ca}, \mathrm{Cu}, \mathrm{Zn}$ and $\mathrm{Pb}$ in SBO stems from the different $\mathrm{C}$ types and functional groups distribution in the three materials (Table 1). 13 C NMR spectroscopy measurements yielded the functional groups data in Table 1. This analytical technique allows identifying the reported $\mathrm{C}$ types, but not obtaining their breakdown into more specific components. For example, the carboxyl (COX), phenoxy (PhOY), methoxy and amine (OMe + $\mathrm{NR}$ ) groups cannot be broken down into free carboxylic acid, amide, ester, phenol, phenyl ethers, methoxy, and amine groups. Nevertheless, Table 1 shows the following significant differences among the three products. Compared to $\mathrm{CP}$ and IR, SBO contain about half alkoxy (RO) groups and twice more carboxyl (COX) groups. This is likely due to the hydrolysis of ester bonds in $\mathrm{CP}$ and formation of SBO carboxylate groups in the alkaline reaction medium. Potentiometric titration measurements yielded further details on the chemical nature of SBO. The authors did not carry the same measurements for $\mathrm{CP}$ and IR, due to their poor solubility properties.

Potentiometric titration allowed obtaining the breakdown of the SBO COX, PhOY and OMe and $\mathrm{NR}$ groups into carboxylates $\left(\mathrm{COO}^{-}\right)$, amide $(\mathrm{CON})$, phenol $(\mathrm{PhOH})$, phenoxy (PhOR), and amine (NR) groups. The results of these measurements indicated that, in SBO, $92 \%$ of the $\mathrm{COX}$ groups are in $\mathrm{COOH}$ form and $56 \%$ of $\mathrm{PHOY}$ are in $\mathrm{PhOH}$ form. They also suggested the higher content of elemental $\mathrm{N}$ in SBO, compared to $\mathrm{CP}$ and IR, to arise from the presence of NR groups. These functional groups are the likely cause of the stronger capacity of SBO to complex and transport the $\mathrm{K}, \mathrm{Ca}, \mathrm{Cu}, \mathrm{Zn}$ and $\mathrm{Pb}$ elements into the reaction soluble hydrolysate.

The data in Table 1 is not normally provided in as much detail for materials of biological sources, as those investigated in the present work. Montoneri et al. (2011) developed a specific analytical protocol to investigate the nature of the molecular pool representing these materials. For the specific use of SBO as diet supplement, Table 2 reports the conventional data on the product proximates' composition. The data in Table 2 is consistent with the data in Table 1. The functional groups given in Table 1 are associated to the proximates listed in Table 2. For example, the OR and OCO groups may be associated to the polysaccharide fraction. The $\mathrm{Ph}$ and $\mathrm{PhOY}$ groups may be associated to the lignin fraction. The COX and NR groups may be associated to the protein fraction of the material.

\subsection{Animal Diets and Live Performance}

The animals were fed with the control diet (T1) and with the treatment diets containing SBO at $0.1 \%$ (T2) and $0.2 \%$ (T3) concentration, over two fattening periods, from 0 to 14 days and from 14 to 42 days. For the two periods, Table 3 reports the diets' formulations and chemical compositions. The T1, T2 and T3 diets in each period have close nitrogen and energy content (see also Table $1 \mathrm{~S}$ in supplementary material file).

Table3. Formulas and chemical composition ( $\mathrm{g} / \mathrm{kg}$ as-fed basis, unless otherwise indicated) for experimental diets used in the first (0-14 days) and second (14-45) fattening periods.

\begin{tabular}{|l|l|l|l|l|l|l|}
\hline & \multicolumn{3}{|c|}{ First period (0-14 days) } & \multicolumn{3}{l|}{ Second period (14-45 days) } \\
\hline & T1 (control) & $\begin{array}{l}\text { T2 }(0.1 \% \\
\text { SBO) }\end{array}$ & $\begin{array}{l}\text { T3 (0.2 } \\
\% \text { SBO) }\end{array}$ & T1 (control) & $\begin{array}{l}\text { T2 (0.1 } \\
\text { \% SBO) }\end{array}$ & $\begin{array}{l}\text { T3 (0.2 } \\
\% \text { SBO) }\end{array}$ \\
\hline Ingredients & & & & & \\
\hline Corn flour & 450 & 440 & 430 & 460 & 460 & 460 \\
\hline Barley flour & 109 & 119.5 & 130 & 191.5 & 189.5 & 188.5 \\
\hline Hamlet protein (HP200) & 142 & 140 & 138 & 120 & 120 & 120 \\
\hline Extract of soy flour 44\% & 100 & 100 & 100 & 90.0 & 90.0 & 90.0 \\
\hline Sweet whey powder & 70.0 & 70.0 & 70.0 & 50.0 & 50.0 & 50.0 \\
\hline Soft wheat bran & 50.0 & 50.0 & 50.0 & & & \\
\hline Vegetable oil & 21.5 & 23.0 & 23.5 & 22.0 & 23.0 & 23.0 \\
\hline Potato protein & 10.0 & 10.0 & 10.0 & 15.0 & 15.0 & 15.0 \\
\hline Calcium carbonate & 18.0 & 17.0 & 17.0 & 18.0 & 18.0 & 18.0 \\
\hline Monocalcium phosphate & 20.0 & 20.0 & 20.0 & 23.0 & 23.0 & 23.0 \\
\hline
\end{tabular}


Pigs' Husbandry as Case Study to Test Effects of Vegetable Residues' Hydrolysates on Animals

\begin{tabular}{|c|c|c|c|c|c|c|}
\hline Sodium chloride & 3.0 & 3.0 & 3.0 & 3.0 & 3.0 & 3.0 \\
\hline Lysine hydrochloride & 3.0 & 3.0 & 3.0 & 4.0 & 4.0 & 4.0 \\
\hline DL methionine & 1.0 & 1.0 & 1.0 & 1.0 & 1.0 & 1.0 \\
\hline Vitamin mineral premix & 2.5 & 2.5 & 2.5 & 2.5 & 2.5 & 2.5 \\
\hline SBO & 0.0 & 1.0 & 2.0 & 0.0 & 1.0 & 2.0 \\
\hline \multicolumn{7}{|l|}{ Chemical Composition $^{\mathrm{a}}$} \\
\hline Dry matter & 896 & 894 & 895 & 893 & 891 & 892 \\
\hline Crude protein & 197 & 193 & 196 & 184 & 181 & 185 \\
\hline Crude fat & 54.4 & 54.4 & 52.1 & 44.2 & 43.7 & 47.3 \\
\hline Crude fiber & 38.7 & 36.3 & 38.2 & 39.9 & 39.1 & 40.4 \\
\hline Ash & 63.5 & 67.6 & 65.9 & 70.7 & 69.8 & 70.2 \\
\hline Starch & 390 & 387 & 390 & 435 & 435 & 434 \\
\hline Digestible energy, $\mathrm{MJ} / \mathrm{kg}$ & 14.4 & 14.4 & 14.4 & 14.3 & 14.3 & 14.3 \\
\hline Net energy, MJ/kg & 10.7 & 10.7 & 10.7 & 10.7 & 10.7 & 10.7 \\
\hline
\end{tabular}

${ }^{a}$ Analytical data determined as reported in section 2. Calculated values for these analytes and for NDF, ADF, $A D L$ and amino acids are reported in the Supplementary material file.

In the present work testing a research product not yet known in the market, a first very important result was the animals' mortality. This was generally very low. The animals' death rate was zero for all groups in the first fattening period. In the second fattening period, the dead animals were two for the $\mathrm{T} 1$, one for the $\mathrm{T} 2$ and one for the T3 groups. Apparently, the mortality rate in each treated $\mathrm{T} 2$ and $\mathrm{T} 3$ groups was half that of the control T1 group. The dead animals were too few to run a statistical analysis and make a reasonable, reliable assessment of the significance level of this apparent result. It is a fact that, over the control and treated groups, the average death rate was $3.9 \%$. This value is in the normal range for pigs of the same age and

Table4. Animals' feed average daily intake $(g)$ in each fattening period, ${ }^{a}$ and average intake calculated over the entire duration of test, for males' groups and females' groups treated with control and treated diets in Table 3

\begin{tabular}{|l|l|l|l|l|l|}
\hline & \multicolumn{3}{|c|}{ Feed Intake $(\mathrm{g})$} & \multicolumn{2}{l|}{ Statistical parameters } \\
\hline & T1 (control) & T2 $(0.1 \%$ SBO) & T3 $(0.2 \%$ SBO $)$ & P & SEM \\
\hline Males & & & & & \\
\hline D0-D14 & 518 & 481 & 525 & 0.35 & 22 \\
\hline D14-D42 & 932 & 915 & 907 & 0.92 & 42 \\
\hline D0-D42 & 785 & 764 & 774 & 0.81 & 23 \\
\hline Females & & & & & \\
\hline D0-D14 & 478 & 520 & 444 & 0.17 & 27 \\
\hline D14-D42 & 881 & 874 & 881 & 0.74 & 8 \\
\hline D0-D42 & 747 & 756 & 736 & 0.52 & 12 \\
\hline
\end{tabular}

${ }^{a}$ First period from day zero to 14 (D0-D14), second period from day 14 to day 42 (D14-D42), entire test duration from day zero to day 42 (D0-D42).

${ }^{b}$ Significance level of effect of treatment $(P)$ and standard error of means (SEM) from statistical analysis of feed intake data in each row.

Table 5 reports the animals' growth performance. The data are averages of the data collected for male and female groups, in each control and treated group. For males, there are no significant effects of the diets with added SBO compared to the control diet. On the contrary, for females, the average growth of the

ARC Journal of Animal and Veterinary Sciences weight, as those fed with the diets in Table 3. The anatomical and pathological examination of the dead animals did not evidence abnormalities possibly caused by the treatment diets.

Table 4 reports the feed average daily intake for the 54 males' group and 54 females' group, separately, in each fattening period, and the average intake calculated over the entire duration of the test. In each period, there are no significant differences in the intake of the control (T1) and of the treated diets (T2 and T3). Females tend to intake less feed than males, but this difference is not proven by the statistical analysis of the males' and females' pooled intake values. 
Pigs' Husbandry as Case Study to Test Effects of Vegetable Residues' Hydrolysates on Animals

Table5. Animals'growth performance. Data as averages calculated over males' groups only and females' groups only, in each control and treated group

\begin{tabular}{|c|c|c|c|c|c|}
\hline & \multicolumn{3}{|c|}{ Weight $(\mathrm{W})$ and daily growth rate $(\mathrm{DG})^{\mathrm{a}}$} & \multicolumn{2}{|c|}{ Statistical parameters } \\
\hline & T1 (control) & $\mathrm{T} 2(0.1 \% \mathrm{SBO})$ & T3 (0.2\% SBO) & $\mathrm{P}$ & SEM \\
\hline \multicolumn{6}{|l|}{ Males } \\
\hline W D0 & 7.86 & 7.78 & 8.14 & 0.22 & 0.15 \\
\hline W D14 & 12.3 & 11.8 & 12.4 & 0.47 & 0.4 \\
\hline W D42 & 27.6 & 24.9 & 27.6 & 0.14 & 1.0 \\
\hline DG D0-D14 & 319 & 284 & 307 & 0.64 & 26 \\
\hline DG D14-D42 & 506 & 464 & 531 & 0.38 & 38 \\
\hline DG D0-D42 & 444 & 402 & 454 & 0.23 & 22 \\
\hline \multicolumn{6}{|l|}{ Females } \\
\hline W D0 & 7.72 & 7.71 & 7.24 & 0.14 & 0.18 \\
\hline W D14 & $11.9 \mathrm{a}$ & $12.1 \mathrm{a}$ & $10.4 \mathrm{~b}$ & 0.02 & 0.4 \\
\hline W D42 & 25.7 & 26.6 & 23.9 & 0.21 & 1.0 \\
\hline DG D0-D14 & 302 & 315 & 229 & 0.14 & 27 \\
\hline DG D14-D42 & 490 & 516 & 480 & 0.63 & 27 \\
\hline DG D0-D42 & 427 & 449 & 396 & 0.32 & 24 \\
\hline
\end{tabular}

${ }^{a}$ Average weight $(W, \mathrm{~kg})$ at day zero $(\mathrm{D} 0), 14$ (D14) and $42(\mathrm{D} 42)$, and daily growth $(\mathrm{DG}, \mathrm{g})$ over the first (DO14) and second (D14-42) fattening periods, and over the entire duration of the experiments (D0-D429; values followed by different letters are significantly different at $P<0.05$.

${ }^{b}$ Significance level of effect of treatment $(P)$ and standard error (SEM) from statistical analysis of $W$ and DG data in each row.

Table 6 reports the feed conversion rate, calculated from the average daily feed intake in Table 4 divided by the average daily growth rate in Table 5. The data shows no significant differences between the control and the treated groups. Over the entire duration of the fattening trials (D0-D42), the females treated with the SBO T2 diet show apparently better-feed conversion rate than the female $\mathrm{T} 1$ and $\mathrm{T} 3$ groups. This results from the apparently higher daily growth of the T2, compared to T1 and T3 groups.

Table6. Feed conversion index (FCI, w/w) in each fattening period and over the entire duration of test. ${ }^{a}$ Data as averages calculated over males' groups only and females' groups only, in each control and treated group.

\begin{tabular}{|l|l|l|l|l|l|}
\hline & \multicolumn{2}{|l|}{ Feed Conversion Index (FCI) } & \multicolumn{2}{l|}{ Statistical Parameters $^{\mathrm{a}}$} \\
\hline & $\mathrm{T} 1$ (control) & $\mathrm{T} 2(0.1 \% \mathrm{SBO})$ & $\mathrm{T} 3(0.2 \%$ SBO $)$ & $\mathrm{P}_{\mathrm{T}}$ & SEM \\
\hline Males & & & & & \\
\hline FCI D0-D14 & 1.70 & 1.71 & 1.76 & 0.93 & 0.13 \\
\hline FCI D14-D42 & 1.95 & 2.03 & 1.72 & 0.53 & 0.20 \\
\hline FCI D0-D42 & 1.80 & 1.93 & 1.71 & 0.41 & 0.11 \\
\hline Females & & & & & \\
\hline FCI D0-D14 & 1.70 & 1.67 & 2.22 & 0.31 & 0.22 \\
\hline FCI D14-D42 & 1.83 & 1.70 & 1.88 & 0.45 & 0.09 \\
\hline FCI D0-D42 & 1.78 & 1.69 & 1.90 & 0.29 & 0.09 \\
\hline
\end{tabular}

${ }^{a}$ First period from day zero to 14 (D0-D14), second period from day 14 to day 42 (D14-D42), entire test duration from day zero to day 42 (DO-D42).

${ }^{b}$ Significance level of effect of treatment $(P)$ and standard error of means (SEM) from statistical analysis of FCI data in each row.

\section{DISCUSSION}

The lack of effects on pigs' growth and mortality in the present work indirectly indicates that, at the tested concentration, SBO are not toxic. The animals exhibited no signs of toxicity, and no pathologies related to the SBOsupplemented diets. Biagini et al. (2016) reported similar conclusions in the study performed on rabbits fed with the same SBO and at the same concentrations in the feed. The agreement between the two studies performed on different animal constitutes an encouraging data's base line for focusing further studies to meet regulatory requirements and to market SBO as multipurpose bio-based chemicals. One important aspect for regulatory compliance is the presence of heavy metals in SBO (Table 1). The present study did not comprise any specific experiment to address this issue. The reason is that the experiments by Biagini et al (2016) and 
Sortino et al.(2012) performed with the same SBO have excluded potential toxicity by SBO' $s$ heavy metal accumulation in rabbits meat, soil and plants. On this basis, no risk for human health can reasonably be expected, even at the highest SBO $0.2 \%$ concentration in feed and at $140 \mathrm{~kg} \mathrm{ha}^{-1}$ dose applied in cultivation soil.

The data obtained in the present pig study and in the previous rabbit study (Biagini et al., 2016) do not confirm the economic expectations proposed in the vitro pigs' cecal fermentation study by Montoneri et al. (2013). The reduced protein $\mathrm{N}$ mineralization during fermentation reported by these authors allowed hypothesizing enhanced meat production upon using protein diets added with SBO. This SBO effect on animal growth has not been evidenced in both the pigs' and rabbits' husbandry studies. However, the reduced protein mineralization is likely to have a positive environmental effect in reducing the ammonia content in manure and emission of GHG from the animal production industry. Ji et al. (2006) have reported that humic substances (HS) mined from different geological sites, and used as dietary supplements for weaning pigs, reduce ammonia emission from manure by $16-18 \%$. Montoneri et al. (2013) have measured similar ammonia reduction in the in-vitro pigs' cecal fermentation in the presence of 0.05-0.2 \% SBO. This shows that SBO are similar to HS not only for chemical nature (Tabasso et al., 2015), but also for properties. It is also a further argument supporting the compliance of SBO with the Italian regulation on fertilizers (Presidente della repubblica, 2010).

Two other studies have reported reduction of ammonia in SBO assisted anaerobic fermentation of municipal biowastes (Francavilla et al., 2016) and cow manure Riggio et al., 2017) carried out in bioreactor dedicated to biogas production. These findings have contributed in starting the construction of the hydrolysis prototype at the Acea Pinerolese waste treatment plant (see Section 1) under the EU cofunded LIFE16 ENV/IT/000179 LIFECAB project within the LIFE2016 project proposals. The project specific aim is to produce SBO in sufficient quantities, use it as additive in the Acea plant biowaste fermentation reactors, and validate in real operational environment the SBO assisted anaerobic fermentation process yielding biogas and digestate with reduced ammonia content.

ARC Journal of Animal and Veterinary Sciences
Under the above circumstances and perspectives, it is worthwhile to build on the established research base line and to carry on further studies dedicated to assessing the SBO compliance with specific countries' regulatory requirements, and the positive economic and/or environmental effects in the chemical industry, agriculture and animal production activities.

\section{CONCLUSiON}

The results of this in vivo pigs' study and the previous in vivo rabbits' study confirm that SBO supplemented diets do not affect negatively the growth and health status of animals. The similarity of chemical nature and properties of SBO and natural humic substances support the compliance of SBO with the Italian regulation on fertilizers. These facts encourage further studies dedicated to assessing SBO compliance with specific countries' regulatory requirements, in order to scale up SBO production to commercial level and market the products for use in the chemical industry, agriculture, and animal husbandry.

\section{ACKNOWLEDGMENTS}

This work was carried partly with Regione Piemonte funds within the Biochemenergy project (www.biochemenergy.it) and with Ministero delle Politiche Agricole funds within the Agrienergia project. In addition, the authors acknowledge Polytechnic of Torino for contributing through the funding project Starting Grant RTD (project number: 54_RSG17NIR01).

\section{REFERENCES}

[1] AOAC, 2006. Official Methods of Analysis, 18th ed. Off. Assoc. Anal. Chem., Arlington, VA, USA.

[2] A.USL di PIACENZA, 2017. Comitato Etico. Available on line: http://www.ausl.pc.it/ comitato_ etico/(accessed on 22 September 2017)

[3] Biagini, D., Gasco, L., Rosato, R., Peiretti, P.G., Gai, F., Lazzaroni, C., Montoneri, C., Ginepro, M., 2016. Compost- sourced substances (SBO) as feedstuff additives in rabbit production. Anim. Feed Sci. Technol. 214, 66-76.

[4] European Commission, 2017. European Union Register of Feed Additives pursuant to Regulation (EC) No 1831/2003. Available on line: https://ec.europa.eu/food/sites/food/files/ safety/docs/animal-feed- eu- reg- comm register_feed_additives_1831-03.pdf (accessed on 22 September 2017).

[5] Fanimo, A. O., Oduguwa, O.O., Adesehinwa, A.O.K., Owoeye, E.Y., Babatunde, O.S., 2003. Response of weaner pigs to feed rationing and 
frequency of feeding. Livestock Research for Rural Development 15 (6). Available on line: http://www.lrrd.org/lrrd15/6/fani156.html (accessed on 22 September 2017).

[6] Francavilla, M., Beneduce, L., Gatta, G., Montoneri, E., Monteleone, M., Mainero, D., 2016. Waste cleaning waste: ammonia abatement in biowaste anaerobic digestion by soluble substances isolated from biowaste compost. Biochem. Eng. J. 116, 75-84.

[7] Handoo, S., Arora, V., Khera, D., Nandi, P. K., Sahu, S.K., 2012. A comprehensive study on regulatory requirements for development and filling of generic drugs globally. Int. J. Pharm Investig., 99-105. DOI:10.4103/2230973X.104392.

[8] ISO, 2016a. Animal feeding stuffs -Determination of moisture and other volatile matter content. ISO6496:1999. Available on line: https://www.iso.org/ standard/12871.html (accessed on 22 September 2017).

[9] ISO, 2013a. Animal feeding stuffs -Determination of crude ash. Animal feeding stuffs-- Determination of crude ash. ISO 5984: 2002. Available on line: https:// www. iso. org/ standard/37272.html (accessed on 22 September 2017).

[10] ISO, 2013b. Native starch -- Determination of starch content -- Ewers polarimetric method. ISO 10520:1997. Available on line: https:// www.iso.org/standard/18589.html (accessed on 22 September 2017).

[11] ISO, 2014. Animal feeding stuffs -Determination of nitrogen content and calculation of crude protein content -- Part 1: Kjeldahl method. ISO 5983-1:2005. Available on line: https://www.iso.org/ standard/39145 .html(accessed on 22 September 2017).

[12] ISO, 2016b. Animal feeding stuffs -Determination of fat content. ISO 6492:1999. Available on line: https: //www.iso.org/ standard/12865.html (accessed on 22 September 2017).

[13] ISO, 2017. Animal feeding stuffs -Determination of crude fibre content -- Method with intermediate filtration. ISO 6865:2000. Available on line: https://www.iso.org/ standard/13377.html (accessed on 22 September 2017).

[14] Ji, F., McGlone, J. J., Kim, S. W., 2006. Effects of dietary humic substances on pig growth performance, carcass characteristics, and ammonia emission. J. Anim. Sci. 84, 24822490.

[15] Kobayashi, E., Hishikawa, S., Teratani,T., Lefor, A.T., 2012. The pig as a model for translational research: overview of porcine animal models at Jichi Medical University. Transplant Res, 1: 8. DOI: 10.1186/2047-14401:8.

ARC Journal of Animal and Veterinary Sciences
[16] Ministero delle Politiche Agricole e Forestali, Aggiornamento degli allegati 6 e 13 del decreto legislativo 29 aprile 2010, n. 75, recante: «Riordino e revisione della disciplina in materia di fertilizzanti, a norma dell'articolo 13 della legge 7 luglio 2009, n. 88». Decreto 17 gennaio 2017. GU Serie Generale n.52 del 0303-2017. Available on line: http://www. gazzett aufficiale.it/atto/serie_generale/caricaDettaglio Atto/originario?atto.dataPubblicazioneGazzetta $=2017-03-03 \&$ atto.codiceRedazionale $=17$

A01586\&elenco30giorni=false(accessed on 22 September 2017)

[17] Montoneri, E., 2017. Municipal waste treatment, technological scale up and commercial exploitation: the case of bio-waste lignin to soluble lignin-like polymers. In: Morone, P., Papendiek, F., Tartiu, V.E. (Eds.), Food Waste Reduction and Valorisation. Springer International Publishing AG 2017, Switzerland. Chapter 6, pp 79-120. DOI:10. 1007/978-3-319-50088-1.

[18] Montoneri, C., Montoneri, E., Tomasso, L., Piva, A., 2013. Compost derived substances decrease feed protein $\mathrm{N}$ mineralization in swine cecal fermentation. J. Agriculture Sci. 13, 3144. DOI:10.5539/jas.v5n3p.

[19] Montoneri, E., Mainero, D., Boffa, V., Perrone D.G., Montoneri, C., 2011. Biochemenergy: a project to turn a urban wastes treatment plant into biorefinery for the production of energy, chemicals and consumer's products with friendly enviromental impact. Int. J. Global Environmental Issues 11, 170-196.

[20] Morgan, C. A., Whittemore, C. T., Phillips, P., Crooks, P., 1987. The prediction of the energy value of compounded pig foods from chemical analysis. Anim. Feed Sci. Technol. 17, 81-107. DOI:10.1016/0377-8401(87)90007-1

[21] Noblet, J., Fortune, H., Shi, X.S., Dubois, S., 1994. Prediction of net energy value of feeds for growing pigs. J. Anim. Sci. 72, 344-354.

[22] Presidente della Republica, 2010. Riordino e revisione della disciplina in materia di fertilizzanti, a norma dell'articolo 13 della legge 7 luglio 2009, n. 88. Decreto Legislativo 29 aprile 2010, n.75. Available online:http://www. camera.it/parlam/leggi/deleghe/10075dl.htm (accessed on 22 September 2017).

[23] Presidente della Republica, 1992. Attuazione della direttiva n. 86/609/CEE in materia di protezione degli animali utilizzati a fini sperimentali o ad altri fini scientifici. Decreto Legislativo 27 gennaio 1992, n. 116. GU Serie Generale n.40 del 18-02-1992 - Suppl. Ordinario n. 33.Available on line: http://www. gazzettaufficiale.it/eli/id/1992/02/18/092 G0157/sg (accessed on 22 September 2017).

[24] Riggio, V., Rosso, M., Comino, E., Biagini, D., Montoneri, E., 2017. Ecofriendly manure 
anaerobic digestion assisted by soluble biobased substances obtained from anaerobic digestion, composting and chemical hydrolysis of urban bio-wastes. A step forward the integration of urban and agriculture waste managements. J. Chem. Tech. Biotechnol. 92: 1111-1117.

[25] Sortino, O., Dipasquale, M., Montoneri, E., Tomasso, L., Perrone, D.G., Vindrola, D., Negre, M., Piccone, G., 2012. Refuse derived soluble bio-organics enhancing tomato plant growth and productivity. Waste Manage. 32, 1792-1801.

[26] Swindle, M.M., Makin, A., Herron, A.J., Clubb Jr, F.G., Frazier, K.S., 2012. Swine as models in biomedical research and toxicology testing. Vet. Pathol. 49, 344-356. DOI:10.1177/ 0300985811402846.

[27] Tabasso, S., Berto, S., Rosato, R., Marinos, J.A.T., Ginepro, M., Zelano, V., Daniele, P.G., Montoneri, E., 2015. Chemical modeling of acid-base properties of soluble biopolymers derived from municipal waste treatment materials. Int. J. Mol. Sci. 16, 3405-3418.

[28] Università Cattolica del Sacro Cuore. Centro Ricerche Zootecniche, 2017. CERZOO S.r.L. Available on line: http://centridiricerca.unicatt. it/crast-case-history-centro-ricerche-zoot ecniche- cerzoo-s-r-l\#content (accessed on 22 September 2017).

\section{SUPPLEMENTARY MATERIAL}

Calculated Chemical composition of experimental diets (Table 1S)

Document submitted to the ethics committee of the local Italian authority (A.USL di Piacenza, 2017), which contained all experimental details of the planned work

Table1S. Chemical composition ( $\mathrm{g} / \mathrm{kg}$ as-fed basis, unless otherwise indicated) of experimental diets used in the first (0-14 days) and second (14-45) fattening periods. ${ }^{a}$

\begin{tabular}{|c|c|c|c|c|c|c|}
\hline & \multicolumn{3}{|c|}{ First period (0-14 days) } & \multicolumn{3}{|c|}{ Second period (14-45 days) } \\
\hline & $\begin{array}{l}\mathrm{T} 1 \\
\text { (control) }\end{array}$ & $\begin{array}{l}\mathrm{T} 2 \\
(0.1 \% \mathrm{SBO})\end{array}$ & $\begin{array}{l}\text { T3 } \\
(0.2 \% \\
\text { SBO })\end{array}$ & $\begin{array}{l}\mathrm{T} 1 \\
\text { (control) }\end{array}$ & $\begin{array}{l}\text { T2 } \\
(0.1 \% \\
\text { SBO })\end{array}$ & $\begin{array}{l}\mathrm{T} 3 \\
(0.2 \% \\
\text { SBO })\end{array}$ \\
\hline Dry matter & 904 & 904 & 903 & 903 & 903 & 903 \\
\hline Crude protein & 196 & 196 & 195 & 184 & 184 & 184 \\
\hline Fat & 50.5 & 51.7 & 52.0 & 50.3 & 51.2 & 51.1 \\
\hline Crude fiber & 34.2 & 34.4 & 34.6 & 32.0 & 31.9 & 31.9 \\
\hline Ashes & 75.7 & 75.1 & 75.4 & 74.4 & 74.7 & 75.1 \\
\hline NDF & 93.6 & 94.3 & 94.9 & 82.4 & 82.1 & 82.0 \\
\hline ADF & 36.2 & 37.0 & 37.8 & 33.1 & 33.5 & 33.9 \\
\hline ADL & 9.4 & 9.8 & 10.1 & 8.2 & 8.5 & 8.9 \\
\hline Starch & 380 & 378 & 376 & 415 & 414 & 414 \\
\hline Lysine & 12.8 & 12.8 & 12.7 & 12.7 & 12.7 & 12.7 \\
\hline Methionine & 4.1 & 4.1 & 4.0 & 4.0 & 3.9 & 3.9 \\
\hline Cystine & 3.3 & 3.3 & 3.3 & 3.2 & 3.2 & 3.2 \\
\hline Triptophan & 2.3 & 2.3 & 2.3 & 2.1 & 2.1 & 2.1 \\
\hline Threonine & 7.6 & 7.6 & 7.5 & 7.1 & 7.1 & 7.1 \\
\hline Glycine + Serine & 16.7 & 16.6 & 16.5 & 15.0 & 15.0 & 15.0 \\
\hline Leucine & 16.8 & 16.7 & 16.6 & 15.9 & 15.9 & 15.9 \\
\hline Isoleucine & 8.7 & 8.6 & 8.6 & 8.1 & 8.1 & 8.1 \\
\hline Valine & 9.7 & 9.6 & 9.6 & 9.1 & 9.1 & 9.1 \\
\hline Histidine & 4.9 & 4.9 & 4.9 & 4.6 & 4.6 & 4.6 \\
\hline Arginine & 12.1 & 12.0 & 12.0 & 11.0 & 11.0 & 11.0 \\
\hline $\begin{array}{l}\text { Phenylalanine }+ \\
\text { Tyrosine }\end{array}$ & 17.1 & 17.0 & 16.9 & 16.1 & 16.1 & 16.1 \\
\hline $\mathrm{Ca}$ & 11.4 & 11.0 & 11.0 & 11.6 & 11.7 & 11.7 \\
\hline Total P & 8.8 & 8.8 & 8.8 & 8.9 & 8.9 & 8.9 \\
\hline $\begin{array}{l}\text { Disodium } \\
\text { phosphate }\end{array}$ & 5.5 & 5.6 & 5.6 & 5.1 & 6.1 & 6.1 \\
\hline $\mathrm{Na}$ & 1.9 & 1.9 & 1.9 & 1.8 & 1.8 & 1.8 \\
\hline Linoleic acid & 10.2 & 10.1 & 10.0 & 11.1 & 11.1 & 11.1 \\
\hline $\mathrm{CA} / \mathrm{P}$ & 1.3 & 1.2 & 1.2 & 1.3 & 1.3 & 1.3 \\
\hline $\begin{array}{l}\text { Digestible } \\
\text { Energy }\end{array}$ & 14.1 & 14.2 & 14.1 & 14.2 & 14.2 & 14.2 \\
\hline Metabolized & 13.7 & 13.7 & 13.7 & 13.8 & 13.8 & 13.8 \\
\hline
\end{tabular}


Pigs' Husbandry as Case Study to Test Effects of Vegetable Residues' Hydrolysates on Animals

\begin{tabular}{|l|l|l|l|l|l|l|}
\hline Energy & & & & & & \\
\hline Net Energy & 10.1 & 10.1 & 10.1 & 10.0 & 10.0 & 10.0 \\
\hline Gross Energy & 13.8 & 13.8 & 13.8 & 14.1 & 14.1 & 14.1 \\
\hline
\end{tabular}

${ }^{a}$ Data calculated based on diets formulas in Table 3 main manuscript, using Brill formulation feed management systems version 2.03, 2011, Brilliant Alternatives Inc., USA.

Document submitted to the ethics committee of the local Italian authority (A.USL di Piacenza, 2017), which contained all experimental details of the planned work

SCHEMAPERLAPRESENTAZIONEDIUNPROGETTODIRICERCAAISENSIDELDECRETOLEG ISLATIVO116/921

RESPONSABILE DEL PROGETTO DI RICERCA

COGNOME MORLACCHINI NOME MAURO

CODICE FISCALE MRLMRA58E06G535J RESIDENZA VIAMORSELLI16-PIACENZA

DIPARTIMENTO O ISTITUTO DI AFFERENZA: CERZOO (CentrodiRicercheperla Zootecniael' Ambiente)-LOC.POSSESSIONEDIFONDO-S.BONICO-PIACENZA

RESPONSABILE DELL'ESECUZIONE DEGLI ESPERIMENTI COGNOME FUSCONI NOME GIORGIO

CODICE FISCALE FSCGRG59D04D357W RESIDENZA VIAROSSI,19-PIACENZA

DIPARTIMENTO O ISTITUTO DI AFFERENZA: CERZOO (Centrodi Ricercheperla Zootecniael' Ambiente)-LOC. POSSESSIONEDIFONDO-S.BONICO-PIACENZA

RESPONSABILE DELLO STABULARIO

COGNOME MORLACCHINI NOMEMAURO

CODICE FISCALE MRLMRA58E06G535J RESIDENZA VIAMORSELLI16-PIACENZA

DIPARTIMENTO O ISTITUTO DI AFFERENZA: CERZOO (CentrodiRicercheperla Zootecniael' Ambiente)-LOC.POSSESSIONEDIFONDO-S.BONICO-PIACENZA

Medico VeterinarioResponsabiledeicontrolli di cui all'articolo 6 delDecretoLegislativo 116/92

COGNOME BONVICINI NOME FLAVIO

CODICE FISCALE BNVFLV63T31B910I RESIDENZA VIALECADORNA3, CASALPUSTER LENGO(LO)

1Se gliesperimentiimplicanoderoga in base all'articolo 8 e all'articolo 9 ilpresente schema deveessere allegatoallaspecificadomanda

SI PREVEDE DI UTILIZZARE TIPO DI ANIMALE

GLI ANIMALI SARANNO STABULATI NEI LOCALI:

GLI ANIMALI SARANNO UTILIZZATI NEI LOCALI FORNITORI

n. 108

suinettisvezzatiCERZOO

CERZOO

Az.AgricolaSerenaCascinaVincereCamairago(LO)

CodiceAll.:007LO011

TITOLO ED OBIETTIVO DEL PROGETTO DI RICERCA

Efficaciadiunestrattodaresiduivegetaliprovenientidagiardinaggioepotaturadiparchinell'alimentazionedi suinettisvezzati

DURATA DELLA SPERIMENTAZIONE (MASSIMO TRENTASEI MESI) 4mesi

PERSONALECHEATTENDEALLAESECUZIONEDEGLIESPERIMENTIE/OALCONTROLLO

DEGLI ANIMALI (COMPRESO IL RESPONSABILE DEGLIESPERIMENTI) 
Pigs' Husbandry as Case Study to Test Effects of Vegetable Residues' Hydrolysates on Animals

\begin{tabular}{|l|l|l|l|}
\hline COGNOME E NOME & TITOLO DI STUDIO & QUALIFICA & $\begin{array}{l}\text { DIPARTIMENTI/ } \\
\text { ISTITUTO } \\
\text { AFFERENZA }\end{array}$ \\
\hline Mauro Morlacchini & LaureaScienzeAgrarie & Direttore & CERZOO \\
Giorgio Fusconi & LaureaScienzeAgrarie & Ricercatore & CERZOO \\
TizianoGeroldi & Licenza media & Operaio & CERZOO \\
NicoliNazareno & Diploma & Operaio & CERZOO \\
Gianfranco Piva & LaureaScienzeAgrarie & Resp. Scientifico & CERZOO \\
\hline
\end{tabular}

DESCRIZIONE DEI FINI DELL'ESPERIMENTO (ARTICOLO 3 D.LVO 116/92)

Lostudiohaloscopodiverificareglieffettidiunestrattodaresiduivegetali(ERV)provenientidagiardinaggioe potaturadiparchinell'alimentazionedisuinettisvezzati,mediantel'osservazionedeiparametrizootecniciec omportamentalideglianimaliutilizzati,coneventualiesamiclinicieanatomo-

patologicosuisoggettideceduti.Lostudiosaràcondottoutilizzando108suinettisvezzati(54maschicastratie5 4femmine),clinicamentesanisuddivisiin3gruppi(T1,T2eT3),costituitida36soggetticiascuno.Aisuinisarà somministratacomeunicafontealimentareil

mangimecontenenteomenolasostanzaoggettodellostudioallivelloprevistodalloschemasperimentale:1.Gr uppocontrollonegativo(T1):dietadibasestandard;2.Gruppotrattato(T2):dietadicontrolloadditivataconER Vinragionedello0,1\%delladieta;3.Gruppotrattato(T3):dietadicontrolloadditivataconER Vinragionedello 0,2\%delladieta.Glianimalisarannosottopostiacontrolloponderalea 0,21 e42giornidall'iniziodellaprova,c onvalutazionedelleperformance(ingestionealimentare, accrescimentimedigiornalierieindicediconversio ne)neiperiodi0-21,21-42e0-42giornidall' iniziodellaprova.

\section{METODOLOGIAETECNICADELL'ESPERIMENTO}

1) CHE TIPO DI SOFFERENZA SI RITIENE DI INFLIGGERE AGLI ANIMALI? xPOCA O NESSUNA SOFFERENZA

o ALCUNE SOFFERENZE (DI BREVE DURATA)

o ESTREME E INTOLLERABILI SOFFERENZE IN ANIMALI COSCIENTI O FORTI PRIVAZIONI, MUTILAZIONI O TRAUMI

2) ANESTESIA SI [ ] NO [X]

Noncompatibileconilfinedell'esperimentoinquantolapresenzadisostanzeanestetizzantinell' organismoa nimaleinterferisconoconlavalutazionedell'efficaciadellasostanzaoggettodellostudio

3) TIPO DI ANESTESIA

4) GLI ANIMALI SONO SOPPRESSI TRAMITE

Nessunsoggettosaràabbattutoperfinisperimentali.

AL TERMINE DELLE PROCEDURE SPERIMENTALI GLI ANIMALI SONO RIUTILIZZATI SI [ ] $\quad \mathrm{NO}[\mathrm{X}]$

Alterminedellasperimentazioneglianimalientrerannonelnormaleciclodi

allevamentoinquantolasostanzaoggettodellostudiosiconfiguracomeunmangimecomplementare.

DICHIARAZIONE RIFERITA ALLE PRESCRIZIONI DI CUI ALL'ARTICOLO 4 (INEVITABILITA' DEL RICORSO AD ESPERIMENTI SU ANIMALI E NECESSITA' DEL

RICORSO AD UNA SPECIE DETERMINATA ED AL TIPO DI ESPERIMENTO) E DI CUI ALL'ARTICOLO 5(RISPETTO DELLE CONDIZIONI)

Gliesperimentianormadell'art.4prevedononecessariamentel'utilizzodianimali

dellaspecieacuiilprodottoèdestinato,nonpotendosiestrapolareirisultatidaaltrespecieanimalioavvalendosi dimetodialternativiinquantolasperimentazioneèvoltaaverificareglieffettidelprodottoinsulleperformance dicrescitadianimalidellaspeciesuina. 


\section{DOCUMENTAZIONE A CORREDO (BIBLIOGRAFIA, PUBBLICAZIONI, ECC.):}

Oggigiornoèdiventataormaiunapraticadiffusailcompostaggiodellesostanzevegetaliderivantidallaraccolt adellepotaturedialberiodeiresiduivegetalidiortiegiardini.Lalorotrasformazioneavvieneadoperadibatteria erobici,edèresapossibiledall'azioneconcomitanteditrefattori:rapportoCarbonio/Azoto,umiditàeossigen o.IlrapportofralepercentualiinpesodelCarbonioedell'Azoto(C/N)presentinelmaterialidacompostaredeve esserecompresotra30/1e25/1.Seémaggioreilperiododicompostaggiosiallunganotevolmenteelaresasiridu ce.NegliscartivegetaliilrapportoC/Nvariadacirca20/1 (sfalcidiprato)acirca100/1(ramaglietriturate)perra ggiungereilvaloredi500/1(segatura).E'pertantodigrandeimportanzal'aggiuntadisostanzeazotateagliscarti vegetalialloscopodirendererapidoilprocessodicompostaggioediaumentareilpotereconcimantedelprodott ofinito.

L'umiditàel'ossigenazionesiregolanoquasiautomaticamenteinuncumulopreparatoconmaterialitrituratico rrettamenteebenmescolati,bastaqualcheannaffiaturainperiodidisiccitàequalcheoperazionediforatura.Sei lcumuloètroppocompattocomeavvienequandoilcumuloècompostodasolosfalciodipratoodasolefoglie,l'u miditàdivienetroppoelevatael'ossigenazionetropposcarsapercuiilfenomenodicompostaggiolasciailposto aquellonondesideratodiputrefazione(processoanaerobico).

Inquesticasiènecessariomescolarematerialepiùgrossolanoqualetrituratodiramaglie,trucioli,paglia.Alcun esostanzevannodosateconattenzionenelcumuloinquantohannoeffettinegativisullosvolgimentodelcompo staggio.Ricordiamogliaghidiconiferechecompostanocongrandedifficoltàelaceneredilegnacheèutileseun itaalcumuloinpiccoledosimachepuòrallentareilcompostaggioseunitaingrandiquantità.

Ilprodottoutilizzatoinquestostudio,consideratounmangimecomplementare,èstatoestrattoacaldoinambie ntealcalinopercentrifugazioneesuccessivaseparazionedelsolidoinsolubile.

Lasuainclusionenelledieteperanimaliinproduzionezootecnica, vistoilloroelevatotenoreazotato(18\%sult. q.)edinelementiminerali(ceneriparial38\%sult.q.), edall'apportoenergetico(EnergiaLordadi3100kcal $/ \mathrm{kg}$ ) el'assenzadibatteripatogeni,permetterebbelariduzionedel'impiegodifontialimentaritradizionali.

\section{RESPONSABILE DELL'ESECUZIONE DELL'ESPERIMENTO DR.FUSCONIGIORGIO}

PIACENZA, 14NOVEMBRE 2011

\section{IL RESPONSABILE SCIENTIFICO}

(Prof.GianfrancoPiva)

IL DIRETTORE DEL CENTRO DI SAGGIO

(Dr.MauroMorlacchini)

Citation: M. Morlacchinia, G. Fusconia, C. Montonerib, R. Nisticòc, E. Montonerid. Pigs' Husbandry as Case Study to Test Effects of Vegetable Residues' Hydrolysates on Animals. ARC Journal of Animal and Veterinary Sciences. 2017; 3(3):11-23. doi: dx.doi.org/ 10.20431/2455-2518.0303003.

Copyright: (c) 2017 Authors. This is an open-access article distributed under the terms of the Creative Commons Attribution License, which permits unrestricted use, distribution, and reproduction in any medium, provided the original author and source are credited. 